\title{
EFFECTIVENESS CONSUMING PINEAPPLE (ANANAS COMOSUS) AND STAR FR UIT (AVERRHOA CARAMBOLA L) TOWARD PLAQUE SCORE
}

\author{
Irmanita Wiradona $^{\bowtie 1}$, Prasko $^{2}$
}

\begin{abstract}
ABSTRAK
Buah belimbing dan nanas merupakan salah satu buah yang memiliki kandungan air dan serat yang banyak. Nanas sumber vitamin $C$ dan mangan, buah ini juga mengandung subtansi yang dapat menjaga kekuatan tulang dan membantu pencernaan. Buah segar mengandung $10 \%$ gula, setengahnya adalah sukrosa sisanya glukosa dan fruktosa. Buah nanas yang kaya akan serat dapat dipercaya meningkatkan produksi saliva (air liur), membersihkan gigi dan mulut serta memperkuat gusi. Sedangkan belimbing mengandung senyawa epitekin yang bersifat bakterisid. Tujuan penelitian ini adalah untuk mengetahui efektifitas mengkonsumsi buah belimbing dan buah nanas terhadap skor plak.

Penelitian ini merupakan penelitian eksperimen dengan rancangan Pre and Post Test Group Design. Sampel penelitian adalah siswa MI Darut Taqwa Meteseh, Tembang, Semarang sebanyak 60 siswa dibagi 4 kelompok intervensi. Intervensi yang dilakukan adalah mengkonsumsi jus belimbing, jus nanas, mengunyah belimbing dan nanas. Skor plak gigi diukur menggunakan indeks PHP. Analisis data menggunakan uji t-test.

Hasil penelitian skor plak minum jus belimbing dan mengunyah belimbing dengan $p=0,001$ sehingga ada perbedaan skor plak antara minum jus belimbing dengan mengunyah belimbing. Rerata selisih skor plak kelompok yang minum jus nanas dan mengunyah nanas dengan $p=0,017$ sehingga ada perbedaan rerata selisih skor plak antara minum jus nanas dengan mengunyah nanas. Sehingga mengkonsumsi nanas lebih menurunkan skor plak dibandingkan mengkonsumsi belimbing.
\end{abstract}

Kata kunci : buah belimbing, buah nanas, skor plak.

\section{ABSTRACT}

Pineapple and Star fruit are one of the fruits that has water content and fiber that many. Pineapple sources of vitamin $C$ and manganese, this fruit also contains substances that can maintain bone strength and help digestion. Fresh fruit contains 10\% sugar, half is the remaining sucrose glucose and fructose. Pineapple fruit rich in fiber can reliably increase saliva production (saliva), clean teeth and mouth and strengthen the gums. While starfruit contains epitekin compounds that are bactericidal. Research purposes this is to know the effectiveness of pineapple and star fruit consumption toward plaque score.

This research is an experimental research with the design of Pre and Post Test Group Design. The sample of this research is MI Darut Taqwa Meteseh, Tembang, Semarang as many as 60 students divided by 4 intervention groups. Interventions taken are consuming star fruit juice, pineapple juice, chewing starfruit and pineapple. Dental plaque scores were measured using the index PHP. Data analysis using a t-test.

The research result from score plaque drink juice star fruit and chew starfruit with $p=0,001$ so there is the difference of plaque score between drinking star fruit juice by chewing star fruit. Score plaque group who drank pineapple juice and chewed pineapple with $p=0.017$ so there was a difference in plaque score between drinking pineapple juice by chewing pineapple. Consume fruit by chewing more down the plaque score compared to drinking fruit juice. Consume pineapple lower plaque than consuming star fruit.

Keywords : starfruit, pineapplefruit, plaque score.

$\overline{1,2)}$ Dosen Jurusan Keperawatan Gigi Poltekkes Kemenkes Semarang

$\bowtie$ : irmanita.wiradona@gmail.com 


\section{PENDAHULUAN}

Kesehatan gigi dan mulut merupakan bagian yang sangat penting dari kesehatan secara keseluruhan. Kesehatan gigi dan mulut di Indonesia perlu diperhatikan, karena karies dan penyakit periodontal merupakan masalah kesehatan gigi dan mulut yang banyak dialami masyarakat. Data World Health Organizatoin (WHO) menunjukkan kerusakan gigi enam puluh hingga sembilan puluh persen dialami oleh anak usia sekolah dan hampir $100 \%$ ditemukan pada orang dewasa (Ticoalu dkk, 2013).

Tingginya angka karies gigi dan rendahnya status kebersihan mulut merupakan permasalahan kesehatan gigi dan mulut yang sering dijumpai pada kelompok usia anak. Prosentase karies gigi paling tinggi adalah pada masa geligi pergantian, yaitu usia pada usia 10-12 tahun, sehingga perawatan gigi pada usia ini sangat penting (Simorangkir, 2010). Riset Kesehatan Dasar (Riskesdas) Nasional tahun 2013 melaporkan bahwa skor DMF-T di Indonesia mencapai 4,6 dan angka prevalensi pengalaman karies penduduk Indonesia adalah 29,9\%.

Plak merupakan deposit lunak yang melekat erat pada permukaan gigi, terdiri atas mikroorganisme yang berkembang biak dalam suatu matrik interseluler jika seseorang mengabaikan kebersihan gigi dan mulutnya (Putri dkk, 2011). Berdasarkan posisinya pada permukaan gigi, plak diklasifikasikan menjadi plak supragingiva,dapat dijumpai setelah 1 jam pembersihan gigi dan plak subgingiva, dapat dijumpai antara tiga sampai 12 minggu setelah awal pembentukan plak supragingiva (Notohartojo dan Lely, 2005). Plak disebut sebagai faktor penyebab utama terjadinya karies dan penyakit periodontal, hal tersebut dikarenakan plak mengandung bakteri patogen yang produk metaboliknya menempel pada permukaan gigi dan gingival (Newman, 2011).

Streptococcus mutans, Lactobacillus spp. dan Candida albicans adalah mikroorganisme dominan yang ditemukan pada plak gigi, memiliki sifat acidogenic dan acidophilic sehingga memiliki kemampuan mengkonversi karbohidrat menjadi asam dan dapat menurunkan $\mathrm{pH}$ lingkungan rongga mulut (Thaweboon dkk., 2011). Zat-zat asam sebagai produk metabolik bakteri dapat dinetralkan oleh saliva sehingga terhindar dari proses demineralisasi gigi. Di dalam saliva terkandung zat-zat seperti substansi antibakteri, senyawa glikoprotein, kalsium, dan florida yang berperan sangat berguna melindungi gigi. Sekresi saliva yang lebih banyak dapat dirangsang dengan proses pengunyahan makanan berserat (Cahyati, 2013).

Sehari-hari banyak dijumpai anakanak yang selalu dikelilingi penjual makanan jajanan, baik di rumah, di lingkungan tempat tinggal hingga di sekolah (Sugianto, 2008). Jajanan merupakan salah satu faktor yang mempengaruhi terjadinya karies gigi. Jajanan umumnya mengandung karbohidrat terutama sukrosa yang merupakan salah satu penyebab terjadinya karies (kariogenik). Selain itu, jajanan umumnya dimakan di luar jam-jam makan atau di antara jam-jam makan. Konsumsi makanan kariogenik yang sering dan berulang-ulang akan menyebabkan $\mathrm{pH}$ plak tetap di bawah normal dan menyebabkan demineralisasi enamel dan terjadilah pembentukan karies (Kidd dan Bechal, 2002).

Anak yang mengonsumsi jajanan kariogenik, seperti biskuit, permen, permen coklat, es krim, cenderung mudah terjadi karies dibandingkan anak yang mengonsumsi jajanan non-kariogenik, seperti sayur dan buah-buahan. Hal ini menyebabkan pentingnya untuk memilih makanan yang tepat untuk dikonsumsi oleh seorang anak. Sebagai ganti biskuit, permen, permen coklat, es krim, sebaiknya diberikan kepada anak buah-buahan segar (Roeslan, 1996).

Buah belimbing dan nanas banyak dijumpai disekitar kita tersedia sepanjang tahun tanpa mengenal musim dan harganya relatif murah. Belimbing adalah dari familia 
Oxalidaceae dengan spesies Averrhoa carambola (Anonim, 2008a). Buah belimbing kandungan epikatekin, mineral (kalium, besi, magnesium, fosfor, kalsium, natrium, kuprum, mangan, selenium, dan seng) dan vitamin (vitamin $\mathrm{C}$, thiamin, riboflavin, niacin, vitamin $\mathrm{B} 6$, folat, vitamin B12, vitamin A dan vitamin E) (Anonim, 2008b).

Epikatekin yang terdapat dalam buah belimbing memiliki kemampuan dalam mengurangi pembentukan plak gigi yang terutama disebabkan oleh Streptococcus mutan dengan cara bakterisidal yang mengakibatkan terganggunya struktur tiga dimensi protein sel bakteri sehingga menjadi terbuka dan acak tanpa merusak struktur kerangka kovalennya sehingga protein pada sel bakteri terdenaturasi, aktivitas biologisnya rusak dan menyebabkan protein tidak mampu menjalankan fungsinya. Kemampuan epikatekin dalam menghambat proses glikosilasi, bekerja secara kompetitif dengan glukosiltransferase (GTFs) dalam mereduksi sakarida yang merupakan bahan dasar proses glikosilasi, sehingga pembentukan polisakarida ekstraselular pada bakteri terhambat (Erycesar, G., 2007).

Nanas merupakan salah satu buah yang mengandung serat dan air. Dalam nanas terdapat kandungan serat sebesar 1,4 gram dan air sebesar 86,37 gram tiap 100 gram daging buah nanas (Sidi, dkk., 2014). Kandungan klor, iodium, fenol pada buah nanas mempunyai efek membunuh bakteri. Klor bereaksi dengan air membentuk hipoklorit yang bersifat bakterisidal. Iodium merupakan salah satu zat bakterisidal terkuat, bekerja dengan cepat dan hampir semua kuman patogen dibunuh. Iodium dipercaya dapat menggumpalkan protein. Fenol juga merupakan salah satu antiseptik dengan khasiat bakteri, yaitu bekerja dengan cara mendenaturasi protein sel bakteri (Rakhmanda, 2008).

Buah nanas (Ananas comosus) mengandung vitamin (A dan $\mathrm{C}$ ), kalsium, fosfor, magnesium, besi, natrium, kalium, dekstrosa, sukrosa (gula tebu), dan enzim bromelain yang dipercaya sebagai enzym antibakteri. Buah nanas mudah didapatkan, dan harganya murah. Masyarakat biasa menggunakannya sebagai antibakteri, antiinflamasi, antikoagulan, dan antikanker (Bitange dkk., 2008). Pada penelitian terdahulu, buah nanas dapat menghambat pertumbuhan bakteri Streptococcus mutans, Escherichia coli, dan Vibrio cholera (Putra, 2008).

Penelitian sebelumnya membuktikan bahwa belimbing mempunyai kadar hambat minimum (KHM) terhadap pertumbuhan Streptococcus mutans pada konsentrasi 50\% (Arifiany, 2007). Penelitian Kartikasari E, 2012 buah belimbing manis (Averrhoa carambola L.) dapat berpengaruh terhadap penurunan jumlah koloni bakteri Streptococcus sp. Sedangkan mengkonsumsi nanas dapat menurunkan jumlah koloni bakteri Stretococcus sp (Marsela dkk, 2015).

Tujuan penelitian ini adalah mengetahui efektifitas mengonsumsi buah belimbing dan nanas terhadap skor plak gigi pada anak usia 10-12 tahun.

\section{METODE PENELITIAN}

Jenis penelitian ini quasi eksperiment dengan rancangan yang digunakan adalah Pre and Post Test Group Design.

Populasi dalam penelitian ini adalah anak usia 10 - 12 tahun di Yayasan Darul Taqwa. Besar sampel penelitian ditentukan dengan menggunakan rumus federer : (n1)(t-1) $\geq 15$ diperoleh jumlah responden $\geq 6$. Dalam penelitian ini memerlukan 4 kelompok perlakuan dimana masing-masing kelompok perlakuan berjumlah 15 responden sehingga banyaknya responden berjumlah 60 sampel. Kelompok 1 : mengunyah belimbing, Kelompok 2 : mengunyah nanas, Kelompok 3 : minum jus belimbing, Kelompok 4 : minum jus nanas. Responden mengunyah buah masing-masing sebanyak 100 gram dengan 32 kunyahan. Sedangkan responden yang minum jus sebanyak $100 \mathrm{ml}$. Pengukuran skor dengan menggunakan 
indeks PHP (Index Plaque Personal Hygiene Performance).

Data hasil penelitian kemudian dilakukan uji normalitas menggunakan uji Shapiro-wilk, dilanjutkan uji homogenitas menggunakan Levene test. Data penelitian yang berdistribusi normal dan Homogen maka dapat dilanjutkan dengan uji paired $t$ test.

\section{HASIL DAN PEMBAHASAN}

Sebelum dan setelah dilakukan intervensi pada masing-masing kelompok, dilakukan pengukuran skor plak dengan pemberian disclosing gel. Pengukuran skor plak ini dilakukan menurut indeks $P H P$ (Index Plaque Personal Hygiene Performance). Distribusi skor plak yang telah diukur pada masing-masing kelompok dapat dilihat pada tabel berikut ini :

Tabel 1. Rerata Skor Plak Sebelu m dan Sesudah Minum Jus Belimbing dan Jus Nanas

\begin{tabular}{ccccc}
\hline Variabel & \multicolumn{2}{c}{ Rerata } & & Keterangan \\
\cline { 2 - 3 } & $\begin{array}{c}\text { Minum jus } \\
\text { Belimbing }\end{array}$ & $\begin{array}{c}\text { Minum } \\
\text { jus Nanas }\end{array}$ & P & \\
\hline Skor Plak & 0,4773 & 0,5453 & 0,529 & $\begin{array}{c}\text { Tidak } \\
\text { Bermakna }\end{array}$ \\
\hline
\end{tabular}

Rerata selisih kelompok skor plak yang minum jus belimbing 0,4773 sedangkan skor plak minum jus nanas 0,5453. Berdasarkan hasil independent t-test nilai $\mathrm{p}$ $=0,529>0,05$, sehingga dapat dikatakan bahwa tidak ada perbedaan rerata selisih skor plak antara minum jus nanas dengan jus belimbing.

Tabel 2. Rerata Skor Plak Sebelum dan Sesudah Mengunyah Belimbing dan Nanas

\begin{tabular}{ccccc}
\hline Variabel & \multicolumn{2}{c}{ Rerata } & & Keterangan \\
\cline { 2 - 3 } & $\begin{array}{c}\text { Mengunyah Mengunyah } \\
\text { Belimbing }\end{array}$ & Nanas & & \\
\hline Skor Plak & 0,8220 & 1,0610 & 0,156 & $\begin{array}{c}\text { Tidak } \\
\text { Bermakna }\end{array}$ \\
\hline
\end{tabular}

Rerata selisih skor plak kelompok yang minum jus belimbing 0,4773 sedangkan skor plak minum jus nanas 0,5453. Berdasarkan hasil independent t-test nilai $\mathrm{p}$
$=0,529>0,05$, sehingga dapat dikatakan bahwa tidak ada perbedaan rerata selisih skor plak antara minum jus nanas dengan jus belimbing.

Tabel 3. Perbedaan Mengkonsumsi Buah Belimbing dan Buah Nanas terhadap Skor Plak

\begin{tabular}{llcccc}
\hline \multirow{2}{*}{ Variabel } & \multicolumn{2}{c}{ Rerata } & & \\
\cline { 3 - 4 } & & Jus & Mengunyah & Keterangan \\
Belimbing & Skor Plak & 0,4773 & 0,8220 & 0,017 & Bermakna \\
Nanas & Skor Plak & 0,5453 & 1,0610 & 0,001 & Bermakna \\
\hline
\end{tabular}

Berdasar Tabel 3 menunjukkan rerata selisih skor plak kelompok yang minum jus belimbing 0,4773 sedangkan mengunyah blimbing 0,8220 . Berdasarkan hasil independent t-test nilai $\mathrm{p}=0,017<0,05$, sehingga dapat dikatakan bahwa ada perbedaan rerata selisih skor plak antara minum jus nanas dengan mengunyah belimbing.

Rerata selisih skor plak kelompok yang minum jus nanas 0,5453 sedangkan mengunyah nanas 1,0610 . Berdasarkan hasil independent t-test nilai $\mathrm{p}=0,001<0,05$, sehingga dapat dikatakan bahwa ada perbedaan rerata selisih skor plak antara minum jus nanas dengan mengunyah nanas.

Berdasarkan hasil penelitian dapat dilihat sesudah mengunyah buah belimbing terjadi penurunan skor plak secara signifikan $(\mathrm{p}=0,017)$ dibandingkan sesudah minum jus belimbing. Demikian juga skor plak terjadi penurunan secara signifikan $(\mathrm{p}=0,001)$ sesudah mengunyah buah nanas dibandingkan minum jus nanas. Mengunyah makanan berserat seperti buah-buahan dapat membantu membersihkan gigi, contohnya pepaya, nanas, semangka, apel, bengkoang, jambu biji merah adalah contoh dari buahbuahan yang mudah dijumpai dan dapat langsung dikonsumsi dalam keadaan segar (Cahyati, 2013). Menurut Vaswani (2005) dalam Eka dkk (2007), mengkonsumsi makanan berserat tidak akan bersifat merangsang pembentukan plak, melainkan berperan sebagai pengendali plak alamiah atau pembersih alamiah pada permukaan gigi. Pembersihan alamiah ini seperti membantu menyingkirkan partikel-partikel 
makanan dan gula selama proses pengunyahan terjadi.

Besar tekanan pengunyahan setiap subyek penelitian dapat mempengaruhi penurunan nilai indeks plak. Menurut Van der Bilt dkk (2006) dalam Lemos dkk (2006) dan Koc dkk (2010), tekanan kunyah dapat dipengaruhi oleh kekuatan otot pengunyahan, geligi, dan tekanan gigit yang bergantung faktor, antara lain morfologi cranio-facial, umur, jenis kelamin, jaringan periodontal yang mendukung gigi, temporomandibular disorder, dan status gigi seperti jumlah dan posisi gigi, serta ada tidaknya tambalan dan gigi tiruan. Cara mengunyah buah (menggunakan kedua sisi rahang secara bersamaan) dan jumlah kunyah yang dikendalikan (sebanyak 32 kali) seperti pada penelitian yang dilakukan juga dapat mempengaruhi penurunan indeks plak gigi yang terjadi.

Menurut Firdaus dkk (2008) dan Ehizele dkk (2009), penurunan indeks plak dapat terjadi karena mengonsumsi makanan berserat dan padat mengakibatkan meningkatnya intensitas dan lama pengunyahan yang dilakukan. Gerakan mengunyah akan merangsang sekresi saliva yang mengandung agen antibakteri. Saliva juga dapat menghilangkan sisa-sisa makanan atau membilas gigi, menetralisasi zat-zat asam yang ada, dan melarutkan komponen gula dari sisa makanan yang terperangkap dalam sela-sela pit dan fisur permukaan gigi, namun saliva saja belum mampu menghilangkan plak pada gigi.

Kandungan katekin yang terdapat dalam buah belimbing manis adalah epikatekin (Samad, 2008). Epikatekin berfungsi sebagai antioksidan, antibakteri, antivirus, melindungi pertumbuhan sel yang tidak normal, dan mencegah terjadinya karies gigi (Qitanonq, 2006). Epikatekin juga telah dibuktikan mempunyai efek antikaries karena bersifat bakterisidal (merusak bakteri) dan dapat menghambat aktivitas enzim glukosiltransferase (GFTs) bakteri (Yulianti, 2006). Enzim glukosiltransferase (GFTs) adalah enzim yang dimiliki bakteri untuk mensintesis sukrosa menjadi dekstran atau glukan. Dekstran inilah yang membuat bakteri bisa melekat pada pelikel gigi. Dekstran atau glukan ini dapat diubah kembali menjadi gula oleh bakteri dan kemudian dijadikan sebagai sumber energi bagi bakteri. Sehingga secara tidak langsung dapat dikatakan bahwa enzim glukosiltransferase (GFTs) diperlukan oleh bakteri untuk melekat pada suatu permukaan guna membentuk biofilm (lapisan plak) (Latif, 2008). Bila bakteri tidak dapat melekat pada pelikel, maka bakteri tidak dapat membentuk koloni yang besar sehingga plak gigi pun akan berkurang. Ketidakmampuan bakteri untuk melekat juga dapat membunuh bakteri itu sendiri karena bakteri tidak akan memperoleh sukrosa sebagai sumber makanannya (Latif, 2008).

Buah nanas mengandung enzim bromelin. Enzim bromelin dalam nanas sangat berpengaruh terhadap $p H$ saliva. Zat ini mengimbangi kadar keasaman pada nanas karena mempunyai efek menekan pertumbuhan bakteri Streptococcus mutans pada rongga mulut seseorang, bakteri tersebut menyebabkan plak pada gigi sehingga dengan mengkonsumsi buah nanas produksi saliva meningkat dan dapat membersihkan rongga mulut yang mengakibatkan $p H$ didalam rongga mulut tidak mencapai angka kritis (Rakhmanda, 2010).

Belimbing memiliki kandungan air sebanyak $90 \%$ air dan serat sebanyak 0,9 gram per 100 gram. Sedangkan nanas mengandung air sebanyak $84,2 \%$ dan serat sebanyak 1 gram per 100 gram. Buahbuahan memiliki kemampuan untuk melakukan self cleansing terhadap rongga mulut. Makanan padat dan juga berserat dari buah dan sayur secara fisiologis akan memaksa mulut manusia untuk menggerus dan menghancurkannya sebelum masuk ke saluran pencernaan selanjutnya, sehingga dapat mendorong sekresi saliva berfungsi sebagai pembersih mulut (Milati, 2009). 


\section{KESIMPULAN}

Berdasarkan hasil penelitian yang telah dilakukan di dapatkan kesimpulan bahwa :

1. Ada perbedaan skor plak antara minum jus dengan mengunyah buah nanas dan belimbing, dimana mengunyah buah lebih banyak menurunkan skor plak dibandingkan dengan minum jus buah.

2. Mengkonsumsi buah nanas lebih banyak menurunkan skor plak dibandingkan mengkonsumsi buah belimbing.

\section{SARAN}

Disarankan kepada masyarakat khususnya anak-anak untuk mengkonsumsi buah yang berserat dan banyak mengandung air terutama belimbing dan nanas dengan cara di kunyah sebagai alternatif mengatasi plak gigi sehingga terhindar dari karies gigi, karena buah berserat dan berair dapat membersihkan gigi secara alami.

\section{DAFTAR PUSTAKA}

Anonim. 2008a. Daftar Budidaya Tanaman Pangan. Sentra Informasi IPTEK. http://www.iptek.net.id/ind/teknologi pangan/index.php?mnu=2 (diakses 23 November 2017).

2008b. Averrhoa Carambola. NewCROPTM Purdue University 1999.

http://www.hort.purd ue.edu/newcrop/ morton/carambola.html\#Keeping\%20 Quality (diakses 23 November 2017).

Arifiany D., 2007. Perbandingan Efek Antibakteri dari Jus Belimbing (Averrhoa carambola) terhadap Streptococcus mutans pada Berbagai Konsentrasi. KTI Fakultas Kedokteran Universitas Diponegoro. Semarang. 1-10.
Bitange N, Zhang W, Shi Y, Wenbin Z. 2008. Therapeutic Application of Pineapple Protease (Bromelain). www.pjbs.org/pjnonline/fin975.pdf (diakses 21 Oktober 2017).

Cahyati, H. W., 2013. Konsumsi pepaya (Carica Papaya) dalam menurunkan Debris Index. Jurnal Kesehatan Masyarakat. 127-136 ISSN 18581196.

DepKes R.I. 2013. Laporan Hasil Riset Kesehatan Dasar (RISKESDAS) Indonesia. Jakarta: Badan Penelitian dan Pengembangan Kesehatan.

Ehizele AO, Ojehanon PI, Akhionbare O. 2009. Nutrition and oral health. $J$ Postgrad Med. 11 (1); 76-82.

Eka C, Eriska R., Feny F., 2007. Perbedaan tingkat kebersihan gigi dan mulut antara anak vegetarian dan non vegetarian di Vihara Maitreya Pusat Jakarta. Jurnal Kedokteran Gigi Indonesia Edisi Khusus PIN IKGA II. $2 ; 79-84$.

Erycesar, G., 2007, Perbandingan Efek Antibakteri Jus Stroberi (Fragaria vesca L.) Pada Berbagai Konsentrasi Terhadap Streptococcus mutans, Semarang: Artikel Karya Tulis Ilmiah. Universitas Diponegoro.

Firdaus T., Eriska R., Dede H. 2008. Index plaque differences between before and after chewing apples. Proceeding Asian Oral Health Care and 2nd ASEAN Meeting on Dental Public Health ; 13-9.

Hidayati, V.R., M.Chair, E., Yuliana, R.K., 2010, Efek Penggunaan Tiga Pasta Gigi Terhadap Perbedaan Status Kebersihan Mulut dan pH Saliva Anak Usia 10-12 Tahun Di Madrasah Ibtidaiyah Nahdatul Ulama Malang, 
Universitas Negeri Malang. http://eprints.um.ac.id.pdf (diakses 25 Nopember 2017).

Kidd, E., dan Bechal, S.J. 2002. Dasar Dasar Penyakit Karies dan Penanggulangannya. Cetakan 2. Jakarta. EGC : 66-96.

Koc D, Arife D, Bulent B. 2010. Bite force and influential factors on bite force measurements: a literature review. Eur J Dent ; 4; 223-232.

Latif, Henny K. 2008. The Effectiveness Comparison Between Rinsing with 100\% and 25\% Steeped Green Tea Solution Concentrations in Clinically Inhibiting Dental Plaque Formation on Six Dental Surfaces (Clinical Research on FKG UI Students Year 2005-2008). Thesis. Jakarta: Fakultas Kedokteran Gigi Universitas Indonesia.

Lemos AD, Flávia RG, Marcia DS, Rafael de LP, Maria BDG. 2006. Chewing performance and bite force in children. Braz J Oral Sci ; 5 (18); 1101-1108.

Lestari, S. dan Malahayati, C, 2004, Pengaruh Makan Apel Dalam Pembentukan Plak Pada Anak-anak Panti Asuhan Al-Khairiyah. Jurnal PDGI. Jakarta; 54,1

Marsela, S., Probosari, N., dan Setyorini, D. 2015. Pengaruh Mengonsumsi Buah Nanas (Ananas comosus L.merr) dan Buah Pir (Pyrus bretschneideri) Terhadap Jumlah Koloni Sterptococcus sp. Dalam Saliva Anak Usia 10-12 tahun. J K G Unej. 12(1): 11-15.

Milati, N, 2009, Jangan Remehkan Kesehatan Gigi dan Mulut Anak-anak http://lovemydentist.multiply.com/jou rnal (diakses 28 Nopember 2017).

Notohartojo, I.T., Lely, S.N.A., 2005, Hubungan Kebersihan Gigi Dan Mulut Dengan Pengetahuan Dan Sikap Responden Di Beberapa Puskesmas Di Provinsi Jawa Barat, Media Litbang Kesehatan. P. 14 No. 4.

Newman M.G, Takei H.H, Caranza F.A, 2011. Carranza's Clinical periodontology Elsevier health sciences. $137-139$

Putra, A., 2008. Perbandingan Efek Antibakteri Jus Nanas (Ananas comosus L.merr) pada Berbagai Konsentrasi terhadap Streptococcus mutans.

www.eprints.undip.ac.id/24278/ 1 /Adi_Putra.pdf (diakses 21 Oktober 2017).

Putri, M.H., Herijulianti, E., Nurjannah, N., 2011, Ilmu Pencegahan Penyakit Jaringan Keras Dan Jaringan Pendukung Gigi, 3th ed, Jakarta: EGC., P. 91-110.

Qitanonq. 2006. Ilmu Budidaya Tanaman Kakao. Available from http://www.kompas.co.id (diakses 18 Oktober 2017).

Rakhmanda, A.P. 2008. Perbandingan Efek Antibakteri Jus Nanas (Ananas comosus L.merr) Pada Berbagai Konsentrasi Terhadap Streptococcus mutans.Karya Tulis Ilmiah Fakultas Kedokteran Universitas Diponegoro Semarang.

Roeslan, B.O. 1996. Imunologi Kelainan Di Dalam Rongga Mulut. Journal of The Indonesian Dental Association. Jakarta: FKG US AKTI. 
Samad, S. 2008. Perbandingan Efek Antibakteri dari Jus Belimbing (Averrhoa carambola) Terhadap Streptococcus mutans pada Waktu Kontak dan Konsentrasi yang Berbeda. Skripsi. Medan : Fakultas Kedokteran Gigi Universitas Sumatera Utara.

Sidi NC, Widowati E, Nursiwi A. 2014. Jurnal Aplikasi Teknologi Pangan. Surakarta: Indonesian Food Technologists ;3:122.

Simorangkir, Dewi S. 2010. Hubungan Pola Jajan dengan Pengalaman Karies Gigi Murid Kelas VI SD Islam An-Nizam Medan. Skripsi. Medan: Fakultas Kedokteran Gigi Universitas Sumatera Utara.

Sugiyanto, W. H. 2008. Kebiasaan Jajan Di Sekolah Dan Kontribusinya Terhadap Total Asupan Serta Tingkat Kecukupan Zat Gizi (Energi, Protein, Vit.A dan Zat Besi) Pada Anak SD. http://eprints.undip.ac.id/26012/ (diakses 25 Oktober 2017).

Tanzer M. J., Livingston J, Thompson M. A. 2007. The Microbiology of Primary Dental Caries. Journal of Dental Education. Vol. 65, No. 10; 1028 1037.

Thaweboon, S., Nakaparksin, J., Thaweboon, B. 2011, Effect of Oil Pulling on Oral Medicine, Asia J public Health, Vol. 2, No. 2, Thailand.

Ticoalu, R.L., Wicaksono, D.A., dan Zuliari, K., 2013. Gambaran Kebutuhan Perawatan Karies Gigi pada Siswa Sekolah Menengah Atas di Kecamatan Lembeh Selatan Kota Bitung. Jurnal e-GIGI Universitas Sam Ratulangi. Manado.
Yulianti N, Samad R. 2006. Efek Berbagai Jenis Teh yang Diminum terhadap Pertumbuhan Plak. Jurnal PDGI; 56(Pt 2):65-9. 